\title{
Energy Values of Registered Corn Forage Hybrids in France over the Last 20 Years Rose in a Context of Maintained Yield Increase
}

\author{
Aurélie Baldy1, Marie-Pierre Jacquemot1, Yves Griveau1, Cyril Bauland², Matthieu Reymond1*, \\ Valérie Mechin $^{1 *}$ \\ ${ }^{1}$ Institut Jean-Pierre Bourgin, INRA-AgroParisTech, CNRS, Université Paris-Saclay, Versailles, France \\ ${ }^{2}$ UMR de Génétique Végétale, INRA-Univ-Paris-Sud-CNRS-AgroParisTech, Ferme du Moulon, Gif-Sur-Yvette, France \\ Email: *matthieu.reymond@inra.fr, *valerie.mechin@inra.fr
}

How to cite this paper: Baldy, A., Jacquemot, M.-P., Griveau, Y., Bauland, C., Reymond, M. and Mechin, V. (2017) Energy Values of Registered CornForage Hybrids in France over the Last 20 Years Rose in a Context of Maintained Yield Increase. American Journal of Plant Sciences, 8, 1449-1461.

https://doi.org/10.4236/ajps.2017.86099

Received: April 21, 2017

Accepted: May 24, 2017

Published: May 27, 2017

Copyright (C) 2017 by authors and Scientific Research Publishing Inc. This work is licensed under the Creative Commons Attribution International License (CC BY 4.0).

http://creativecommons.org/licenses/by/4.0/

cc (i) Open Access

\begin{abstract}
The cultivation of corn silage has developed in France since the 1970s to reach 1.5 million of hectares nowadays. Since 1998, a feeding value criterion (namely UFL for "Unité Fourrage Laitière") has been taken into account to register forage varieties in the French forage maize hybrids catalog in addition to other criteria related to plant agronomical performances such as yield, earliness and lodging resistance. It is frequently stated that the improvement of plant's agronomic performances would led to a decline in forage energy value. Decline of "Unité Fourrage Laitière" values has been repeatedly reported and the expected increase was not yet visible in 2002. In the present study, a set 47 early and mid-early hybrids commercialized in France between 1958 and 2015 has been cultivated in 3 locations in France. "Unité Fourrage Laitière" values and yield have been estimated in order to shed light on the evolution of feeding value criteria during this period and to conclude on the evolution of " $\mathrm{Un}$ ité Fourrage Laitière" values since the introduction of this criterion for registration. Results obtained in our study demonstrated a recent rise in "Unité Fourrage Laitière" value in a context of strong yield increase. This increase was not necessarily attributable to high cob proportion in the harvested silage. Breeder's work since the 2000's has succeeded to offer hybrids that recover "Unité Fourrage Laitière" values similar to the ones of hybrids from the 1960's (Royal, 1960, $91 \mathrm{UFL} / 100 \mathrm{~kg} \mathrm{DM}$ ). We propose to accentuate this effort targeting the enhancement of lignocellulosic cell wall digestibility to breed for future forage maize hybrids.
\end{abstract}


Keywords

Maize, Forage, UFL Value, Yield, Breeding

\section{Introduction}

From 1950, in the post-war context, the main objective in France was to feed the population and the priority was therefore to increase crops productivity and thus maize selection was devoted to grain yield enhancement. The cultivation of corn silage has developed in France since the 1970s thanks to the commercialization of early varieties adapted to the rainy climate of dairy farming areas. In 1985, a specific heading for forage was created in the official French maize hybrid registration catalog. Since 1986, the entries in this catalog are made in "corn grain" or in "corn forage" catalogs [1]. In this context, since 1970, the French cultivated areas with corn silage have increased from 350000 ha to 1.5 million ha nowadays [2]. During this period, the whole plant yield increased from 6 t.DM.ha ${ }^{-1}$ to $20 \mathrm{t} \mathrm{DM} \mathrm{ha}^{-1}$ for forage corn. In France, for several decades net energy has been expressed in a barley feed unit (one kg of standard barley contains one Unité Fourragère, one UF). The net energy value for milk production in dairy cattle was also given according to the French standards and expressed as UFL (UF Laitières, with $1 \mathrm{UFL}=7.1 \mathrm{MJ} \cdot \mathrm{kg}^{-1} \mathrm{DM}$ ).

Predictive models have been established during the 1990's to predict the energy UFL value of corn forage [3] and have just been confirmed and slightly updated in 2016 [4]. Equation M4.2 (update of the Model 4 equation developed by Andrieu in 1995 [3] has been established to predict the UFL value using two variables: the total nitrogen content $(\mathrm{MAT}=$ protein) and the in vitro measured dry matter digestibility according to the method developed by Aufrère (DCS). All these tools are currently used by breeders and by the varieties registration committee to evaluate maize hybrids.

Since 1998, this UFL criterion has been taken into account to register maize hybrid in the forage catalog [5] in addition to other criteria related to plant agronomical performance such as yield, earliness and lodging resistance. Even if this energy criterion was originally intended to increase the impact given to UFL for commercializing maize varieties dedicated to silage, the importance given to agronomical criteria always prevailed. It is frequently stated that the improvement of plant's agronomic performance would led to a decline in forage energy value. Indeed, decline of UFL value has been reported before 1998 and the expected increase was not yet visible in 2002 [1]. Keep in mind that an increase of only $5 \%$ of the UFL ( $/ 100 \mathrm{~kg} \mathrm{DM})$ value results in the production of $1.8 \mathrm{~kg}$ additional milk per day and per cow [6], which represents an additional income of $200 €$ per cow and per year for the farmer.

In the present study, a set 47 early and mid-early hybrids commercialized between 1958 and 2015 coming from INRA and 7 breeding companies has been cultivated in 3 locations in France. Energy values along with yield have been es- 
timated in order to shed light on the evolution of UFL during this period of selection including 1998, the year when UFL criteria became mandatory to register maize forage varieties in France.

\section{Materials and Methods}

\subsection{Genetic Material and Field Trials}

A set of 47 forage maize hybrids coming from INRA and 7 breeding companies have been analyzed. These hybrids have been commercialized over the 57 past years in France (from 1958 to 2015). Hybrids registered before 2000 have been produced in Chile during the winter 2015-2016 whereas hybrids registered after 2000 have been provided by the breeding companies.

Field trials were carried out from April 2017 to September 2017 in 3 locations in France in a region of maize forage production: Reclainville (GPS, N: 48'20"18.492 /E: 1'44"46.575), Oucques (GPS, N: 47'49"23.689/E: 1'17"39.793) and Villampuy (GPS, N: 48'2'8.322/E: 1'30'15.35.506). Sowing took place between April $22^{\text {nd }} 2016$ and May $3^{\text {rd }} 2016$ with an average density of 86,000 plants per hectare. Irrigation was provided according to usual farming practices. Silage harvest has been performed between August $26^{\text {th }} 2016$ and September $13^{\text {th }}$ 2016 when percentage of dry matter reached more than 35\% for whole plant biomass and 30\% for plants harvested without cobs. In each location two blocs with all the 47 hybrids were set up, with two successive rows per hybrid in each bloc. One bloc was dedicated to harvest the total above ground biomass, whereas the second one was dedicated to harvest plants without cobs. The two rows per hybrid and per bloc were sampled and each sample has been dried (3 days in a ventilated oven at $55^{\circ} \mathrm{C}$ ) and grinded (hammer miller gondard type with a $1 \mathrm{~mm}$ grid).

\subsection{Analyses and Quantifications}

\subsubsection{Estimation of Yields}

Yield of each row has been estimated using the following equation:

$$
\text { Yield }\left(\mathrm{t} \mathrm{DM} \mathrm{ha}{ }^{-1}\right)=\left(\left(\frac{w}{n}\right) * d\right) * 10^{-3} * \% \mathrm{DM}
$$

where: $w$ is the fresh weight of the two harvested rows (in $\mathrm{kg}$ ); $n$ is the number of plants in the two harvested rows; $d$ is the sowing density and \%DM is the percentage of dry matter estimated using the following equation:

$$
\% \mathrm{DM}=\frac{d w}{f w} * 100
$$

where: $d w$ and $f w$ are the dry weigh and fresh weight of the sample of the two harvested rows per hybrid and per bloc, respectively.

These estimations have been done for each hybrid in each bloc and in each location. Thus, yields obtained on the bloc where all above ground biomass has been harvested were different to the ones obtained on the bloc where plants without cobs were harvested. This allowed us to estimate the following ratio 


$$
\text { Ratio } \frac{(\mathrm{S}+\mathrm{L})}{\mathrm{C}}=\frac{\text { yield }(\mathrm{S}+\mathrm{L})}{[\text { yield }- \text { yield }(\mathrm{S}+\mathrm{L})]}
$$

where: yield $(\mathrm{S}+\mathrm{L})$ corresponds to the yield (in t DM.ha ${ }^{-1}$ ) of the plant without cobs, i.e. yield of stems and leaves. Yield corresponds to the silage yield (in $\mathrm{t}$ $\left.\mathrm{DM} \mathrm{ha}^{-1}\right)$. yield - yield $(\mathrm{S}+\mathrm{L})$ represents the estimated yield of cobs.

\subsubsection{Near Infra-Red Spectroscopy Predictions.}

NIRS spectrum of each ground sample was acquired at IJPB-Versailles (Antaris II analyzer from ThermoFisher). NIRS predictive equations set up in Gembloux [7] were transferred in 2014 in the Antaris II analyzer of IJPB Versailles. These predictive equations allowed us to estimate:

- Ashes content: in percentage of organical matter,

- MAT: nitrogen content in percentage of dry matter

- The DCS: percentage of dry matter enzymatic digestibility according to the method developed by Aufrère et Michalet-Doreau, 1983 [8].

- Starch content and Soluble carbohydrate were potentially completely digestible and are expressed in percentage of DM

- Protein content: is expressed in percentage of DM

- The IVDNSC: in vitro digestibility of the non-starch, non-soluble carbohydrate, non-protein portion calculated according to Argillier et al. [9]:

$$
\text { IVDNSC }=100 * \frac{(\text { DCS }- \text { starch }- \text { soluble carbohydrate }- \text { protein })}{(100-\text { starch }- \text { soluble carbohydrate }- \text { protein })}
$$

\subsubsection{Equation of Energy Value (UFL)}

Different predictive models have been established during the 1990's to predict the energy UFL value of corn forage [3]. The M4 model chosen for the hybrid registration to the official French corn silage catalog has been slightly updated very recently by Peyrat [4]. The UFL value was thus estimated using the M4.2 model described in Peyrat [4]:

$$
\mathrm{UFL}(100 \mathrm{~kg} \text { of OM })=18.77+0.1389 \mathrm{MAT}+0.9491 \mathrm{DCS}
$$

UFL values were then combined to the estimated yield to calculate a UFL per hectare:

$$
\mathrm{UFL}\left(\mathrm{ha}^{-1}\right)=\mathrm{UFL}(100 \mathrm{~kg} \mathrm{DM}) * \operatorname{yield}\left(\mathrm{t}^{\mathrm{DM}} \cdot \mathrm{ha}^{-1}\right) * 10
$$

where UFL is obtained with Equation (5) and yield is calculated with equation (1) and expressed in $t \cdot h a^{-1}$.

\subsection{Statistical Analysis}

Statistical analysis were performed in R using R Studio interface.

Quantifications were done per hybrid per bloc of each location. All the values presented in the results section are the average of the 3 locations for each hybrid.

Boxplot were conducted with the boxplot function under RStudio. The bottom and top of the box are the 25th and 75th percentiles (the lower and upper 
quartiles, respectively), and the band in the box is the 50th percentile (median); whiskers represent minimum and maximum values.

\section{Results and Discussion}

\subsection{Evolution over Time of UFL Values}

In France, forage energy value is quantified using UFL (for $100 \mathrm{~kg}$ of DM; see introduction and materials and methods sections). This criterion has then been used to estimate the energy values of harvested hybrid samples from the field trials carried out in 2016 (see materials and methods section). UFL has also been used in previous studies to estimate energy value of maize hybrids [1] [10]. In order to expand the data set, results from our study have been gathered with the ones from Barrière et al., 1992 [10] (Figure 1(a)) allowing us to examine the evolution of UFL over a large period of time (from 1958 to 1992 from Barrière et al., 1992 and from 1958 to 2015 from experiments carried out in 2016) using hybrids representative of the commercialized ones on this period of time.

Data from Barrière et al. [10] resulted from several fields trials carried out from 1969 and 1990 in Lusignan/France. Irrigation in these field trials was applied in the ones performed after 1975. A wide range of variation of UFL is observable in their study (from 78 to $97 / 100 \mathrm{~kg} \mathrm{DM}$; Figure 1 (a)). It is worth to notice that hybrids used in their study were not specific to forage market due to the fact that this market segmentation did not occur at this time. Indeed, this distinction came out in 1986 (see introduction). Moreover, half of the late hybrids used in their study had low UFL values ( 5 hybrids with UFL below 85). Hybrids carrying the bm3 mutation [11] reported in Barriere et al. [10] were not included in the Figure 1(a). As expected UFL of these bm3 hybrids were high (over 94; [10]).

The 47 early and mid-early hybrids cultivated in 2016 presented in this study were representative of the commercialized maize forage hybrids between 1958 and 2015. Within this period, 1998 was the year when UFL was adopted as a mandatory criterion used for forage hybrid registration in France. Contrary to what is reported in Barrière et al. [10], these 47 hybrids have been evaluated in 3 locations using classical practices of irrigation in all locations. Variation of UFL values from the 47 hybrids was weaker than the variation from Barrière et al. [10] and Surault et al. [1]. Interestingly, 5 hybrids were evaluated both in Barriere et al. [10] and in the present study (Figure 1(a)). Estimation of UFL in both studies for these common hybrids were quite similar (Figure 1(a)) with not always the values from one study being over or below values from the other. This allowed us to analyze jointly results from these studies to assess evolution of UFL over time.

Over the last 57 years, considering the global dataset we observed a wide range of variation of UFL values for any given period (Figure 1(b)). This variation of UFL was not taken into account in Surault et al. [1], however, they revealed a steady decline in UFL values on 248 early hybrids registered from 1958 to 2002. The authors concluded that four years (from 1998 to 2002) of selection after the appearance of the UFL criterion in the French catalog were not sufficient to in- 


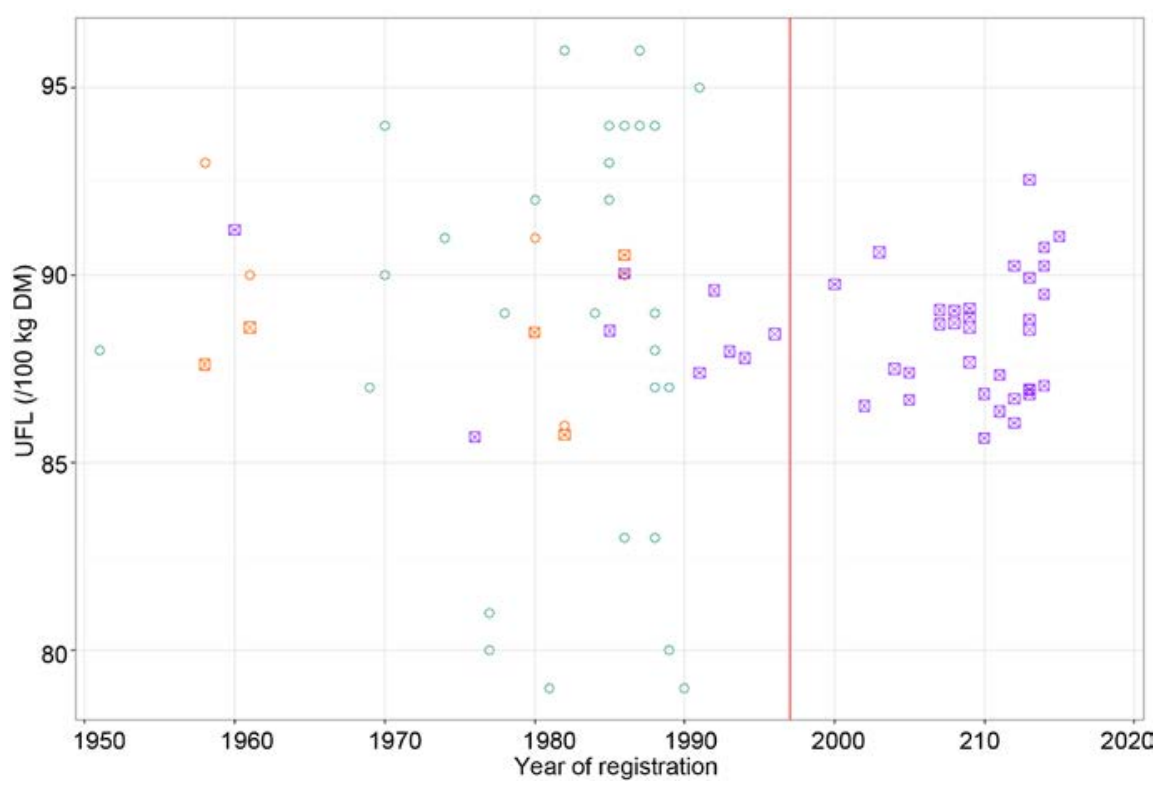

(a)

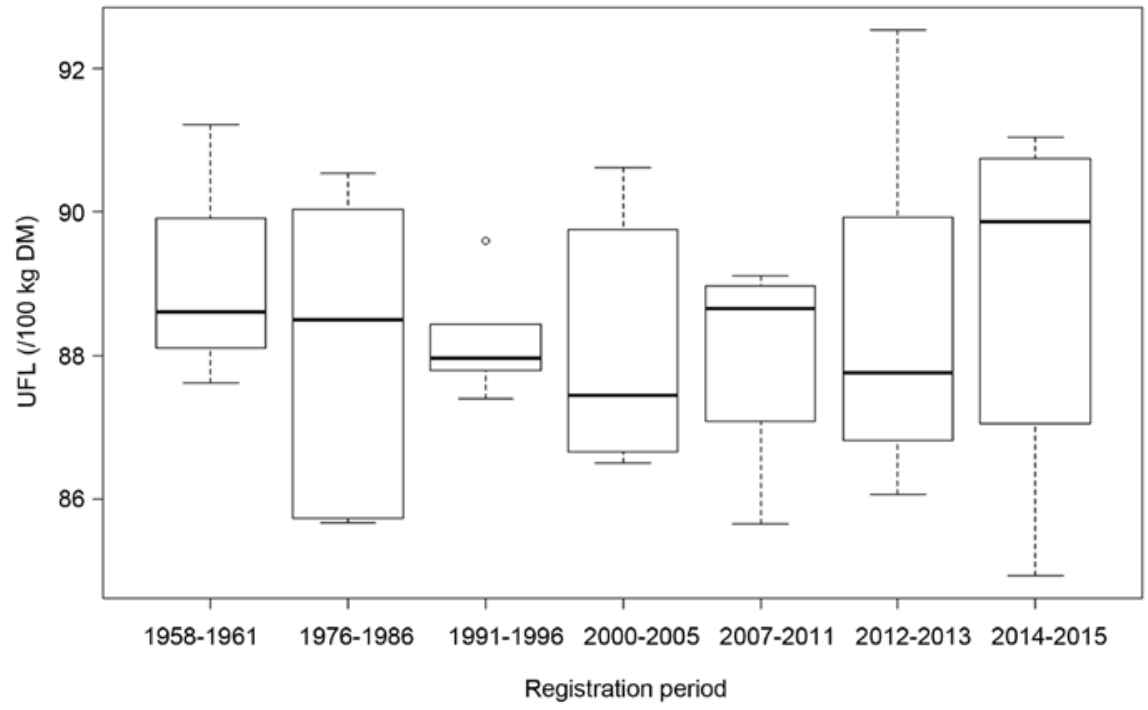

(b)

Figure 1. Evolution over time of energy values (UFL). (a) UFL value of 75 hybrids (33 from Barrière et al. (1992) and 47 from the present study, including 5 common) are represented over time with a different shape and color according to the related study. Squares are the average of the 3 locations presented in the material and method section. Orange circles and orange squares represent the 5 common hybrids that were evaluated in both Barrière et al., 1992 and our study 2016. Green circles are the 28 specifics hybrids from Barrière et al., 1992. Purple squares are the 42 specific hybrids from the present study. The red vertical line represents the date from which UFL criterion was used for silage hybrids registration; (b) Boxplot representing the variation of the UFL over time on our dataset. The bottom and top of the box are respectively the lower and upper quartiles, the band in the box is the median. The 7 classes of years from 1958 to 2011 are not continuous due to the absence of hybrids representing some years.

itiate the rise of the UFL values of registered hybrids. Our study allows us to confirm their observations since UFL values decreased in trend for hybrids reg- 
istered until 2007 (Figure 1(b) and Table 1). After 2007, the trend is reversed and a rise in UFL values is appreciable. Over the period 2014-2015, this increase became noteworthy and confirmed the role of companies in selecting higher energy-value hybrids (Figure 1(b) and Table 1). It is important to note that since 2012, based on the hybrids used in this study, the vast majority of the 7 companies possess hybrids with UFL values comparable to those of Royal registered in 1960 (91 UFL/100kg DM, Figure 1(a))) but with yields reaching 17 to $22 \mathrm{t} \cdot \mathrm{ha}^{-1}$ in comparison to the $11 \mathrm{t} \cdot \mathrm{ha}^{-1}$ of Royal.

\subsection{Striking Increase of UFL Values per Hectare over the 57 Past Years}

Over the 47 hybrids cultivated in the present study, yield increased from 11 t.ha ${ }^{-1}$ in 1960 to $22 \mathrm{t} \cdot \mathrm{ha}^{-1}$ in 2014, which reflects a genetic progress of 0.2 $\mathrm{t} \cdot \mathrm{ha}^{-1} \cdot \mathrm{year}^{-1}$. In 2004, Barrière et al. [12] reported a whole plant yield progress of $0.17 \mathrm{t} \cdot \mathrm{ha}^{-1} \cdot \mathrm{year}^{-1}$ for hybrids registered between 1986 and 2000. In the USA, Lauer et al. [13] highlighted an annual rate of forage yield increase of 0.13 to 0.16 t.ha ${ }^{-1}$ since 1930. As exposed in Barrière et al. [12], Lauer et al. [13] did not observed a decrease of the cell wall digestibility during this period. This may be due to a different evolution between American and European germplasm during this period. Indeed, the improvement of maize in Europe has undergone major changes [12], while American material has not deviated too much from the Reid and Lancaster groups.

We decided to compile UFL and yield by estimating UFL per hectare (UFL·ha ${ }^{-1}$, see Materials and Methods section). As expected, UFL $\cdot \mathrm{ha}^{-1}$ strongly increased between 1958 and 2015 (Figure 2(a) and Table 1). This increase is estimated to 110 unit.ha ${ }^{-1} \cdot$ year $^{-1}$ over this period. Knowing that an increase of $5 \%$ of UFL/100 $\mathrm{kg}$ of DM lead to an increase of $1,8 \mathrm{~kg}$ of produced milk by a cow [6], the progress of UFL.ha ${ }^{-1}$ could lead to an increase of $39.6 \mathrm{~kg}$ of milk per hectare and per year by a cattle livestock's, which corresponds to an additional profit of $790 €$ per hectare over the period for the farmer. Then, it is also appreciable to notice that UFL values did not drop off among hybrids showing such

Table 1. Evolution of mean values for UFL, UFL ha ${ }^{-1}$, yields and IVDNSC over registration periods.

\begin{tabular}{cccccccc}
\hline $\begin{array}{c}\text { Registration } \\
\text { period }\end{array}$ & $\begin{array}{c}\text { UFL/100 } \\
\text { kg DM }\end{array}$ & $\begin{array}{c}\text { UFL } \\
\text { UFL.ha }^{-1}\end{array}$ & $\begin{array}{c}\text { Yield } \\
\text { t.DM.ha }\end{array}$ & $\begin{array}{c}\text { Yield (S+L) } \\
\text { DM.ha }\end{array}$ & $\begin{array}{c}\text { Yield of Cob } \\
\text { t.DM.ha }\end{array}$ & $\begin{array}{c}\text { ratio } \\
\text { (Stems + leaves)/ } \\
\text { cobs }\end{array}$ & $\begin{array}{c}\text { IVDNSC } \\
\%\end{array}$ \\
\hline $1958-1961$ & 89.15 & 10117 & 11.19 & 4.33 & 6.86 & 0.65 & 47.13 \\
$1976-1986$ & 88.17 & 12654 & 13.86 & 5.21 & 8.64 & 0.61 & 45.52 \\
$1991-1996$ & 88.24 & 13411 & 15.56 & 5.55 & 10.01 & 0.57 & 45.35 \\
$2000-2005$ & 88.08 & 15878 & 17.70 & 6.95 & 10.75 & 0.67 & 45.04 \\
$2007-2011$ & 88.00 & 15730 & 17.52 & 6.42 & 11.10 & 0.61 & 44.68 \\
$2012-2013$ & 88.36 & 16038 & 17.54 & 6.46 & 11.08 & 0.60 & 44.78 \\
$2014-2015$ & 89.72 & 16282 & 17.76 & 6.50 & 11.26 & 0.58 & 46.23 \\
\hline
\end{tabular}




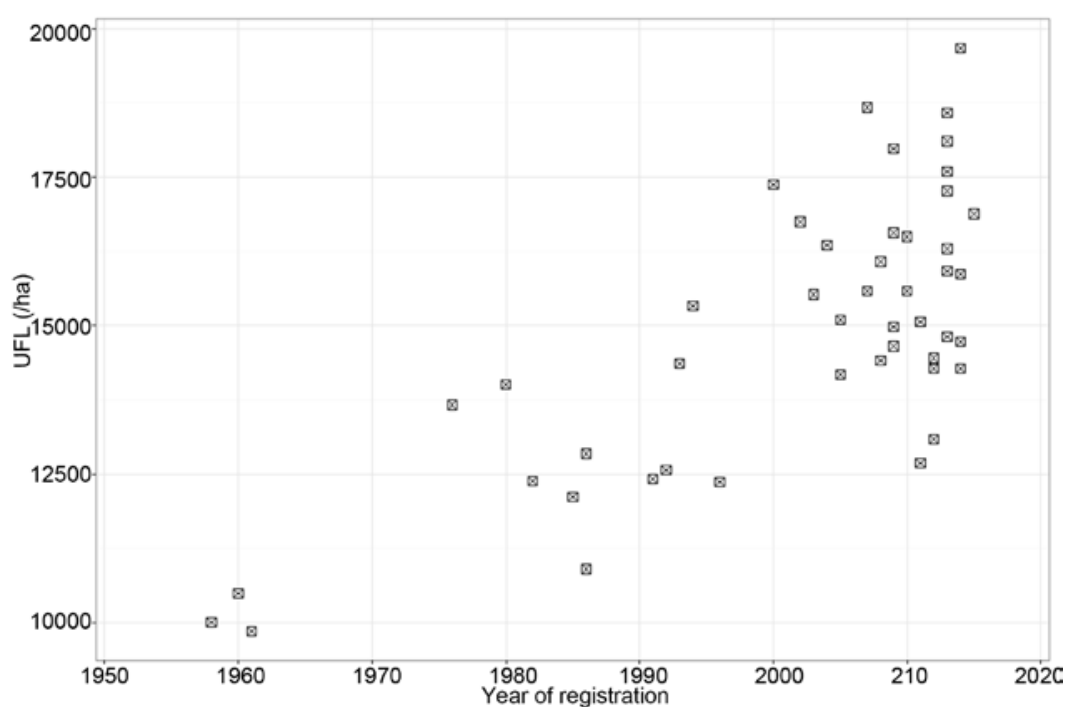

(a)
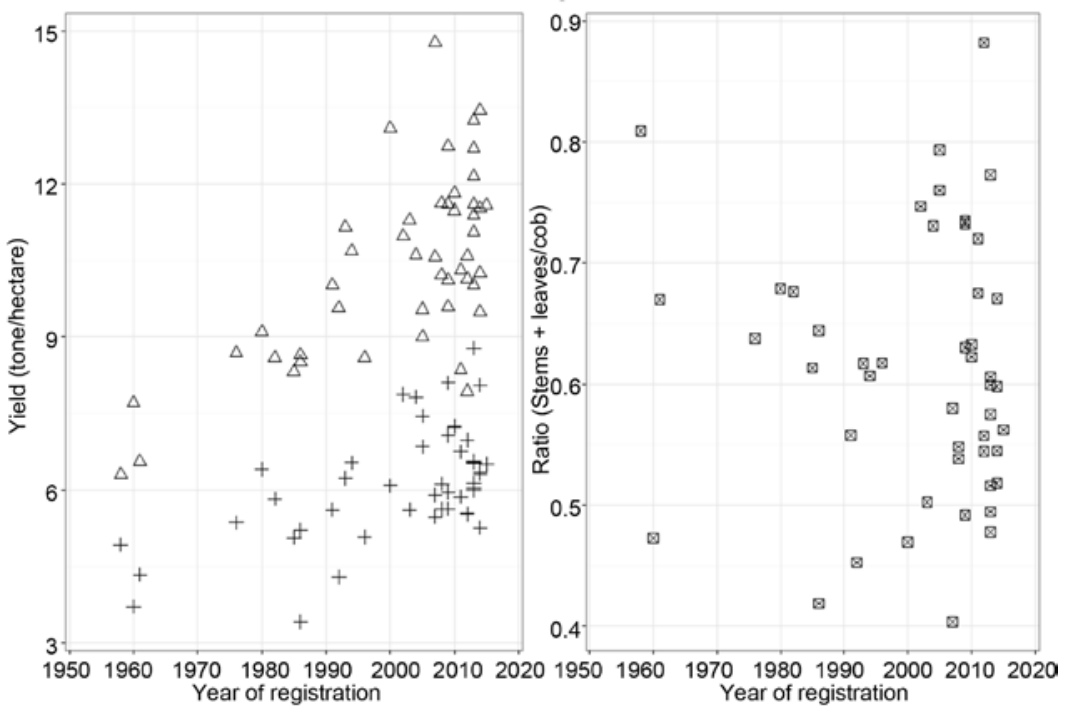

(b)

Figure 2. Evolution of UFL values per hectare (UFL.ha ${ }^{-1}$ ) and yields (t.DM.ha ${ }^{-1}$ ) from 1958 to 2015. (a) Evolution of UFL values (UFL.ha ${ }^{-1}$ ) of 47 hybrids are represented over time. Each dot is the average of the UFL value of the 3 locations presented in the material and method section; (b) Evolutions of whole plants without ears yield: + ) and of cobs yield $(\Delta)$ are represented over time; (c) Evolution of (Stems and leaves)/cobs ratio over time. Hybrids with a ratio equal to 0.9 presented $52 \%$ of cob fraction, hybrids with a 0.7 ratio presented $59 \%$ of cob fraction and at least hybrids with a 0.5 ratio presented $66 \%$ of cob fraction.

an increase of biomass produced. Indeed, that Royal in 1960 reached a UFL at 91 with a yield of $11 \mathrm{t} \cdot \mathrm{ha}^{-1}$ does not imply the same prowess than to ensure in 2015 a UFL of 90 for yields of $20 \mathrm{t} \cdot h \mathrm{a}^{-1}$.

\subsection{Hybrids with Higher Kernel/Cob Fraction Were Not Selected to Improve UFL Values of Modern Hybrids}

Harvested maize forage is composed of lignocellulosic biomass brought by stems and leaves and starch brought by cobs mainly. Energy values and digestibility 
from lignocellulosic and starch fractions are highly different, starch being fully degradable and lignocellulosic fraction being recalcitrant to enzymatic hydrolysis. In order to examine if the increase of yield observed was mainly supported by an increase of cob fraction and/or stems and leaves fraction, biomass produced by the 47 studied hybrids at the 3 locations have also been harvested without cobs (see Materials and Methods section). This allowed us to estimate the evolution of stems and leaves fraction as well as cobs fraction over time (Figure 2(b)). Production of both fractions increased remarkably over time (from 3.4 in 1986 to $8.8 \mathrm{t} \cdot \mathrm{ha}^{-1}$ in 2013 and from 6.3 in 1958 to $14.8 \mathrm{t} \cdot \mathrm{ha}^{-1}$ in 2007 for stems and leaves and for cobs fractions respectively). Hence, hybrids yield increase observed of the last 57 years results from yield improvement of overall organs of the plants (Figure 2(b)). As reviewed by Lorenz et al. [14], in the US Corn Belt in contrast to what has been observed for other crops, gains in maize grain yield over time have also been accompanied by increases in stover yield. However, the different values of increase of both fractions could lead to emergence of modern hybrids with higher cob fraction.

A S + L/C ratio (namely Stems + Leaves fraction divided per Cobs fraction; see Materials and Methods section) has then been estimated for each hybrid. Evolution of this ratio is presented in Figure 2(c). The scarcity of hybrids commercialized before the 80 's did not allow us to conclude on the evolution of this ratio over time. However, it is worth to notice that a wide variation of this ratio remained for the cultivated modern hybrids reflecting absence of selective drift on this trait. The variation of this ratio indicates also that biomass produced by modern hybrids is composed of $55 \%$ to $70 \%$ of cob in weight (ratio from 0,8 to 0,45 respectively; Figure $2(\mathrm{c})$ ). Impact on this $\mathrm{S}+\mathrm{L} / \mathrm{C}$ ratio on UFL values has been investigated (Figure 3). An elevated UFL value was not necessarily brought by a very high cob fraction. This confirm results obtained by Barrière et al. [10] and Surault et al. [1] on 248 early hybrids registered from 1958 to 2002. In their study, a genotypic correlation of 0.36 between kernel content and UFL values highlighted the weak relationship between these two parameters. Thus, a high kernel fraction can contribute to better UFL values, but it is necessary to look at the $\mathrm{S}+\mathrm{L}$ fraction degradability to better understand the observed UFL values.

\subsection{Cell Wall Degradability of the Stems + Leaves Fraction as a Target for Selection to Improve UFL of Future Forage Maize Hybrids}

One could expect to notice an overall decrease of cell wall digestibility of the lignocellulosic biomass fraction (namely IVDNSC for in vitro digestibility of the non-starch, non-soluble carbohydrate and non-protein part of the plant, see materials and methods section) when the quantity of cob increases. Indeed, plant able of bearing heavy cobs would also produce highly lignified or at least reinforced (with lignin or other recalcitrant cell wall constituent) stems to avoid lodging for instance, going hand in hand with a decrease of cell wall degradability. In Figure 4(a), a slight decrease of IVDNSC until 2005 is observed in 


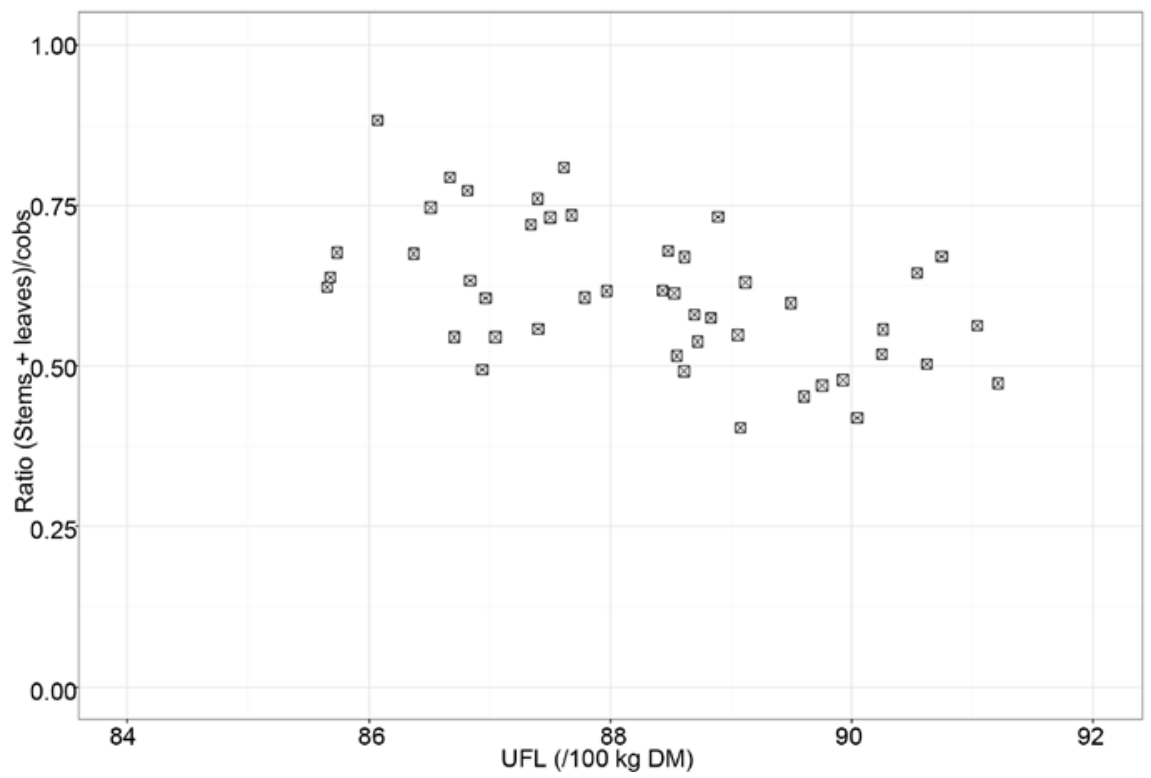

Figure 3. Relationships between the ratio (stems + leaves)/cob and the UFL value for the 47 hybrids.

tendency (Table 1, 3\%). This result corroborates results presented in Surault et al. [1] where a $5 \%$ decrease of $\mathrm{CUD}_{\mathrm{NDF}}$ (in french, Coefficient d'Utilisation Digestive du NDF = Digestive coefficient of cell wall) was reported over the period 1958-2002. Similarly, in 1997 Barrière and Argillier [15] displayed a decrease for in vivo digestibility of hybrids registered between 1989 and 1994 compared to those registered before 1989. Thus, since the adoption in 1998 of the UFL criterion for forage hybrid registration in France, no increase in cell wall degradability was reported so far. As exposed in Barrière et al. [16] alleles allowing good cell wall degradability were probably discarded during decades of breeding for grain yield and stalk stand ability. In 1995, before applying the UFL criteria for silage hybrids registration in France, Argillier [17] questioned the possibility of selecting both for agronomic performance and for elevated maize feeding value. Until 2005, various studies have reported the UFL and cell wall degradability decreases simultaneously with the improvement of agronomic traits. From 2007 to 2015, a trend to cell wall degradability increase has been observed in our study (Figure 4(a)). Moreover, among modern hybrids (registered after 2010), a wide range of IVDNSC variation still remained, suggested that selection did not impose a drift towards lower values of IVDNSC only. Interestingly, UFL values are correlated to IVDNSC (Figure 4(b)) indicating that cell wall digestibility of lignocellulosic fraction played a role in the variation of UFL. Some modern hybrids displayed digestibilities comparable to those of hybrids of the 1960s. Therefore the work of breeders since the 2000's has allowed an efficient germplasm selection (both flint and dent lines) to straighten the UFL values in a context of strong yield increase.

To summarize results obtained in our study, we observed an average rise in UFL values from 2007 to 2015 . Taking into account that IVDNSC is positively 


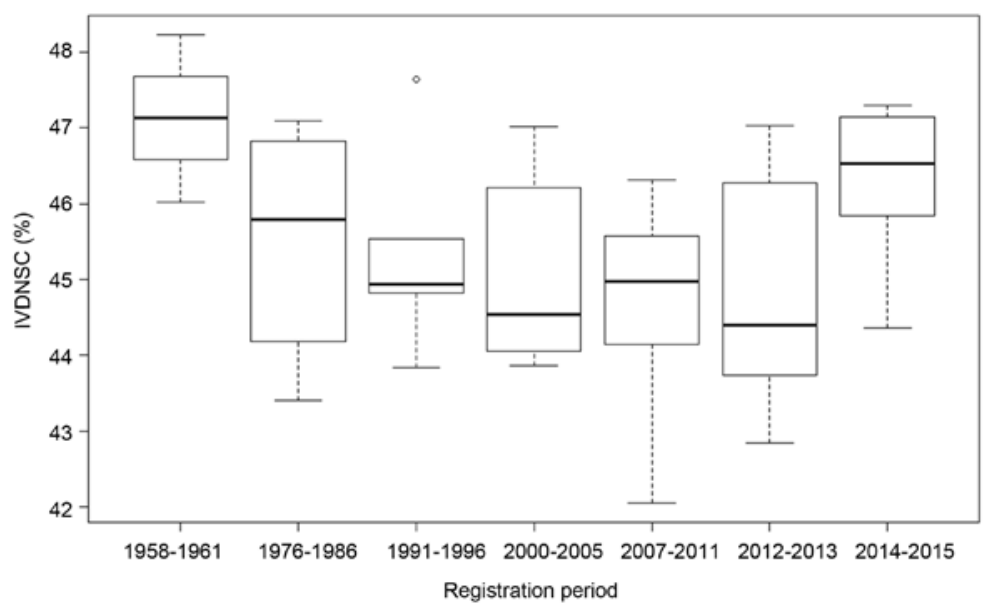

(a)

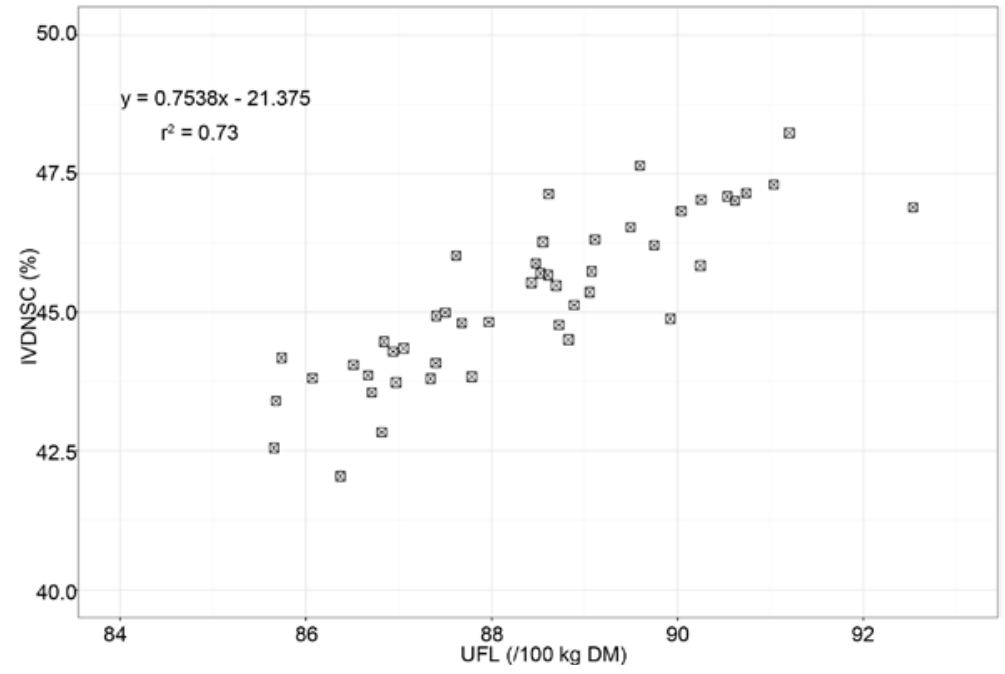

(b)

Figure 4. Evolution of IVDNSC over time and relation with UFL. (a) Boxplot representing the variation of the IVDNSC over time on our dataset. IVDNCS represents the cell wall degradability and is the in vitro digestibility of the non-starch, non-soluble carbohydrate and non-protein part of the plant. The bottom and top of the box are respectively the lower and upper quartiles. The band in the box is the median. Classes of years from 1958 to 2011 are not continuous due to the absence of hybrids representing some years; (b) Relationships between IVDNSC and UFL values. Each dot is the average of the UFL value of the 3 locations presented in the material and method section.

correlated to UFL whatever the value of the $\mathrm{S}+\mathrm{L} / \mathrm{C}$ ratio, we propose to target the enhancement of lignocellulosic cell wall digestibility to breed for future forage maize hybrids. At least, to answer Argillier's question in 1995 [17], our results suggested that it is possible to increase yield without impacting feeding values.

\section{Acknowledgements}

This work has benefited from a French State grant (LabEx Saclay Plant Sciences-SPS, ref. ANR-10-LABX-0040-SPS), managed by the French National 
Research Agency under an "Investments for the Future" program (ref. ANR-11-IDEX-0003-02).

The authors are thankful to Chloé Marchive for her assistance in the writing of the research contract associated with this project, to the private companies involved in this project for their collaboration and for the productive exchanges during the preparation of this manuscript.

\section{References}

[1] Surault, F., Emile, J.C., Briand, M., Barrière, Y. and Traineau, R. (2005) Genetic Variability of Corn Hybrids in Vivo Digestibility. A Review of 34 Years of Measures. Fourrages, 183, 459-474.

[2] Arvalis (2011) Forage Corn in France. https://www.arvalis-infos.fr/_plugins/WMS_BO_Gallery/page/getElementStream.ht $\underline{\text { ml?id=6488\&prop=file }}$

[3] Andrieu, J. (1995) Prediction of Digestibility and Energy Value of Corn Fodder in the Fresh State. INRA Productions Animales, 8, 273-274.

[4] Peyrat, J. (2016) Prediction of the Energy of the Whole Plant, Cell Wall and Starch. Colloque Maïs fourrage et bovins: Nouvelles approches de la valeur alimentaire et de sa valorisation, Paris, 17 Novembre 2016.

[5] Andrieu, J. and Aufrere, J. (1996) Prediction of Digestibility and Energy Value of the Fresh Maize Plant Using Different Methods (Physical, Chemical and Biological). Colloque Maïs Ensilage, Nantes, 61-69.

[6] Barrière, Y. and Emile, J.C. (2000) Corn Fodder. Evaluation and Prospects of Genetic Progression on Food Value Traits. Fourrages, 163, 221-238.

[7] Dardenne, P., Andrieu, J., Barrière, Y., Biston, R., Demarquilly, C., Fremenias, N., Lila, M., Maupetit, P., Rivière, F. and Ronsin, T. (1993) Composition and Nutritive Value of Whole Maize Plants Fed Fresh to Sheep. II. Prediction of the in Vivo Organic Matter Digestibility. Annales Zootechniques, 42, 251-270. https://doi.org/10.1051/animres:19930302

[8] Aufrère, J. and Michalet-Doreau, B. (1983) In Vivo Digestibility and Prediction of Digestibility of Some By-Products. EEC Seminar on Feeding Value of By-Products and Their Use by Beef Cattle, Gontrode, 27-29.

[9] Argillier, O., Hébert, Y. and Barrière, Y. (1995) Relationships between Biomass Yield, Grain Production, Lodging Susceptibility and Feeding Value in Silage Maize. Maydica, 40, 125-136.

[10] Barrière, Y., Emile, J.C., Traineau, R. and Hébert, Y. (1992) Genetic Variability of Corn Silage Digestibility Measured on Standard Sheep. INRA Productions Animales, 5, 248-255.

[11] Vignols, F., Rigau, J., Torres, M.A., Capellades, M. and Puigdoménech, P. (1995) The brown Midrib3 (bm3) Mutation in Maize Occurs in the Gene Encoding Cafeic O-Methyltransferase. The Plant Cell, 7, 407-416. https://doi.org/10.1105/tpc.7.4.407

[12] Barrière, Y., Emile, J.C., Traineau, R., Surault, F., Briand, M. and Gallais, A. (2004) Genetic Variation for Organic Matter and Cell Wall Digestibility in Silage Maize. Lessons from a 34 Year Long Experiment with Sheep in Digestibility Crates. Maydica, 49, 115-126.

[13] Lauer, J.G., Coors, J.G. and Flannery, P.J. (2001) Forage Yield and Quality of Corn Cultivars Developed in Different Eras. Crop Science, 41, 1449-1455.

https://doi.org/10.2135/cropsci2001.4151449x 
[14] Lorenz, A.J., Gustafson, T.J., Coors, J.G. and De Leon, N. (2010) Breeding Maize for a Bioeconomy: A Literature Survey Examining Harvest Index and Stover Yield and Their Relationship to Grain Yield. Crop Science, 50, 1-12. https://doi.org/10.2135/cropsci2009.02.0086

[15] Barrière, Y. and Argillier, O. (1998) In Vivo Silage Feeding Value of Early Maize Hybrids Registered in France between 1958 and 1994. Euphytica, 99, 175-182. https://doi.org/10.1023/A:1018379931874

[16] Barrière, Y., Alber, D., Dolstra, O., Lapierre, C., Motto, M., Ordas, A., Van Waes, J., Vlasminkel, L., Welcker, C. and Monod, J.P. (2005) Past and Prospects of Forage Maize Breeding in Europe. The Grass Cell Wall as a Basis of Genetic Variation and Future Improvements in Feedind Value. Maydica, 50, 259-274.

[17] Argillier, O. (1995) Relationship between Lodging, Food Value and Productivity in Forage Maize. Thesis INA-PG, 173.

\section{Abbreviations}

UFL: for "Unité Fourrage Laitière"

$\mathrm{t} \mathrm{DM} \mathrm{ha}^{-1}$ : tone of dry mater per hectare

UF: one kg of standard barley contains one Unité Fourragère

UF Laitières, with $1 \mathrm{UFL}=7.1 \mathrm{MJ} \cdot \mathrm{kg}^{-1} \mathrm{DM}$

DM: dry matter

MAT: protein content

DCS: the in vitro measured dry matter digestibility according to the method developed by Aufrère

$S+$ L/C ratio: namely Stems+Leaves fraction divided per Cobs fraction

IVCNSC: in vitro digestibility of the non-starch, non-soluble carbohydrate and non-protein part of the plant

$\mathrm{CUD}_{\mathrm{NDF}}$ : Digestive coefficient of cell wall, in french, Coefficient d'Utilisation Digestive du NDF

Submit or recommend next manuscript to SCIRP and we will provide best service for you:

Accepting pre-submission inquiries through Email, Facebook, LinkedIn, Twitter, etc. A wide selection of journals (inclusive of 9 subjects, more than 200 journals)

Providing 24-hour high-quality service

User-friendly online submission system

Fair and swift peer-review system

Efficient typesetting and proofreading procedure

Display of the result of downloads and visits, as well as the number of cited articles

Maximum dissemination of your research work

Submit your manuscript at: http://papersubmission.scirp.org/

Or contact ajps@scirp.org 